\title{
Correction to: Strengthening the Power of Evidence-Based Prevention in Cooperative Extension: A Capacity-Building Framework for Translation Science-Driven Behavioral Health
}

\author{
Richard Spoth $^{1}$ (D) $\cdot$ Nancy Franz ${ }^{2} \cdot$ Alison Brennan ${ }^{3}$
}

Published online: 8 September 2020

(C) The Author(s) 2020

\section{Correcton to: Child \& Youth Care Forum https://doi.org/10.1007/s1056 6-020-09559-0}

The article "Strengthening the Power of Evidence-Based Prevention in Cooperative Extension: A Capacity-Building Framework for Translation Science-Driven Behavioral Health", written by Richard Spoth, Nancy Franz, Alison Brennan, was originally published electronically on the publisher's internet portal on 18 July 2020 without open access. With the author(s)' decision to opt for Open Choice the copyright of the article changed on 13 August 2020 to $\odot$ The Author(s) 2020 and the article is forthwith distributed under a Creative Commons Attribution 4.0 International License, which permits use, sharing, adaptation, distribution and reproduction in any medium or format, as long as you give appropriate credit to the original author(s) and the source, provide a link to the Creative Commons licence, and indicate if changes were made. The images or other third party material in this article are included in the article's Creative Commons licence, unless indicated otherwise in a credit line to the material. If material is not included in the article's Creative Commons licence and your intended use is not permitted by statutory regulation or exceeds the permitted use, you will need to obtain permission directly from the copyright holder.

To view a copy of this licence, visit https://creativecommons.org/licenses/by/4.0/.

Open Access This article is licensed under a Creative Commons Attribution 4.0 International License, which permits use, sharing, adaptation, distribution and reproduction in any medium or format, as long as you give appropriate credit to the original author(s) and the source, provide a link to the Creative Commons licence, and indicate if changes were made. The images or other third party material in this article

The original article can be found online at https://doi.org/10.1007/s10566-020-09559-0.

Richard Spoth

rlspoth@iastate.edu

1 Partnerships in Prevention Science Institute, Iowa State University, 2625 N Loop Drive, Suite 2400, Ames, IA 50010, USA

2 School of Education, Iowa State University, Ames, IA, USA

3 Department of Health and Human Development, Montana State University, Bozeman, MT, USA 
are included in the article's Creative Commons licence, unless indicated otherwise in a credit line to the material. If material is not included in the article's Creative Commons licence and your intended use is not permitted by statutory regulation or exceeds the permitted use, you will need to obtain permission directly from the copyright holder. To view a copy of this licence, visit http://creativecommons.org/licenses/by/4.0/.

Publisher's Note Springer Nature remains neutral with regard to jurisdictional claims in published maps and institutional affiliations. 